\title{
Sustainable Vacation Industry Mobility Criteria in Heritage Cultural Natural Conserved Areas
}

\author{
Titus Hari Setiawan ${ }^{\mathrm{a}, \mathrm{b}}$, Heru Purboyo Hidayat Putro ${ }^{\mathrm{a},{ }^{*}}$, Pradono Pradono ${ }^{\text {a }}$ \\ ${ }^{a}$ School of Architecture, Planning and Policy Development, Institut Teknologi Bandung, Bandung, West Java, Indonesia \\ ${ }^{b}$ Transportation Division of Central Java Provincial Government, Central Java, Indonesia \\ Corresponding author: "purboyohp@gmail.com
}

\begin{abstract}
Transportation and tourism cannot be separated. Both often lack the attention and cooperation of the stakeholders involved. Although each stakeholder has different goals and criteria, they need to work together to achieve the sustainability of tourism destinations. Nature-protected tourism objects and cultural heritage areas have a key role as conservation and tourism areas with specific criteria for preserving natural values, cultural heritage values, and other positive impacts of tourists visiting local communities. Transportation policies as a guideline of tourist mobility must ensure the sustainability of these values. The success of making transportation policy decisions must be supported by all actors involved with their respective goals and criteria. Therefore, multicriteria are needed to measure transportation policies on tourist mobility in sustainable destinations. This paper examines the criteria for transportation policies that support mobility in sustainable nature tourism and cultural heritage protected areas using a multi-actor participatory method. The criterion rating is determined by the number of stakeholders involved and the score assigned by the stakeholders against the selected criteria. The results show that the highest to lowest criteria rank are as follows: comprehensive planning, transportation system Integration, safety, and security, visitor management, accessibility, various transport systems, supporting local entrepreneurs, supporting cultural events, low-impact transportation, operational efficiency, protection of cultural assets, visitors experience and transport equality.
\end{abstract}

Keywords - Sustainable destination mobility; multi-actor multi-criteria; natural-cultural protected area; transport policy.

\section{INTRODUCTION}

Transportation and tourism are so inseparable that we cannot even think of the tourism industry without a transportation system. Transportation provides accessibility and luxury for the tourism industry. How can transportation and tourism be sustainable? Several studies on sustainability, such as criteria for sustainable tourism destinations and sustainable mobility [1]-[7]. The Nature-Cultural tourism protected area is a popular tourist destination and a protected area [8], [9] which has exceedingly rare natural-cultural values but is sensitive to human existence. Many parties worry that there will be a decrease in quality if there is a human presence. Site managers need to balance visitor access needs with conservation goals [8], [9]. There are many concerns that future generations will not be able to enjoy the inheritance, an identity or marker of the existence of a history of ancestral origins in the past. There is a trend that tourist visits in protected areas are quite high, thus threatening damage to natural, cultural resources and destination attractiveness to some extent leading to stagnation and reduction in tourism activity in many destinations [10], [11]. Managers are concerned with the various impacts of visitor and private vehicle use, including increased air and noise pollution, damage to roadside vegetation, lack of parking space, visitor stress, traffic congestion, climate change, and disasters [12]-[21]. Transportation is an important component of nature and culture-based tourism that allows visitors to travel around protected areas and can be used to manage the flow of tourist visits in protected areas. In fact, by designing the transport system carefully, managers can deliver the right number of people to the right place at the right time, thereby preventing the problems of overuse and overcrowding [22].

In debates about the concept of sustainable tourism, sustainable mobility is often neglected [14], [17] even though it is the most important aspect of sustainable tourism development. In decisions making, stakeholders need to balance their interests to create sustainable value [23]. There are many actors involved in tourism areas, so that regional and 
local partnerships are needed by including relevant stakeholders in the decision-making process [24]. Sustainable mobility policies empower participatory processes, partnerships, and multi-stakeholder collaboration [25]. Sustainable mobility policies empower participatory processes, partnerships, and multi-stakeholder collaboration [26], [27]. The realization of sustainable tourism and mobility requires cooperation and the participation of relevant stakeholders in tourism, transportation, and nature-culture preservation that each stakeholder expresses their criteria [28], [29]. The involvement of various stakeholders with their views on their criteria and objectives is very important to achieve sustainable tourism destination development [30][32]. Unlike conditions in other parts of the world that have a single authority to manage protected areas, the Dieng Plateau Tourism area involves many stakeholders in its management. Until now, the planning of the Dieng tourism area has not shown a clear objective, so that the existence of tourism has threatened the decline in natural and cultural values. This study assesses sustainability criteria based on multi-actor participation to measure transportation policies that support mobility in nature-cultural tourism protected areas.

Many studies have been conducted on the mobility of tourists in nature-protected areas, but no one has examined the mobility of tourists in destinations that have natural and cultural values, which is called mix heritage by the World Heritage Center, UNESCO. Dieng Plateau is a tourist destination with extraordinary and rare natural and cultural values or can be equated with 39 Mix Heritage sites in the UNESCO World Heritage Center. Dieng Plateau Tourism Area is a natural tourism area in Central Java Province, Indonesia, with the highest level of tourist visits located on the border of the administrative areas of Banjarnegara and Wonosobo Regencies, which are located in Central Java Province. In the administrative and spatial area of Central Java Province, there are many stakeholders involved in the Dieng Tourism Area, so transportation policies are needed that guideline all interests. In the spatial planning of the tourist area, Dieng has several strategic functions [33] :

- Dieng Temple area (socio-cultural strategic)

- Dieng Plateau Area (environmental carrying capacity)

- Dieng Plateau as a National Tourism Strategic Area.

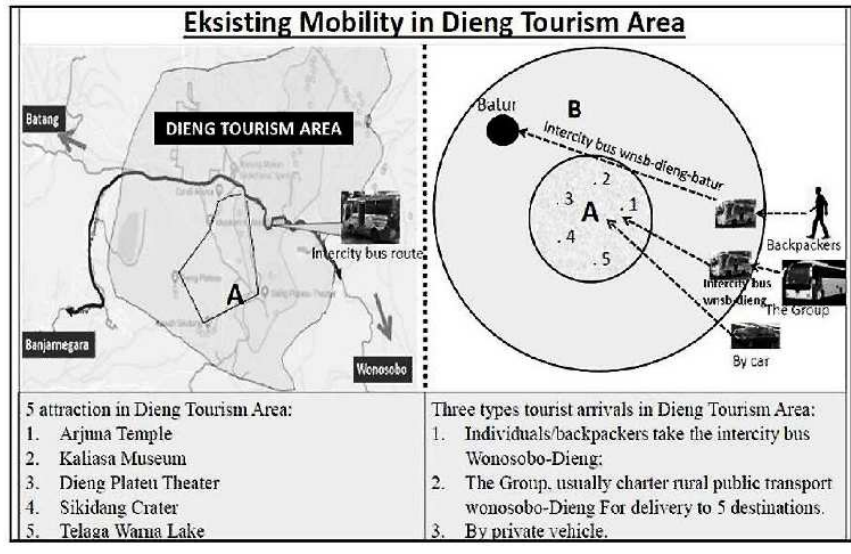

Fig. 1 Existing Mobility in Dieng Tourism Area

Based on the results of the survey and secondary data, this study classified the types of tourist visits in the Dieng tourist area into 4 categories, namely: a) of peak (a quiet working day with visitors under 1000 people); b) half peak (a normal day which is quite crowded with visitors, for example, school holidays 1000 to 10000 people); c) peak on the weekends (holidays with the high number of visits $=10,000$ to 50,000 ); d) extraordinary peak (At the time of cultural events such as the Dieng Culture Festival the number of visitors is above 50,000 people, and even the number of visitors to the last Dieng Culture Festival event was 177,000 people).

\section{MATERIAL AND METHOD}

Destinations are understood as complex adaptive systems in which various subsystems interact dynamically with the tourism subsystem, interwoven with the involvement of relevant stakeholders [27], [32]. Mobility in this protected area of cultural nature tourism is a strategic area that involves various subsystems, namely: tourism, transportation, nature conservation, and cultural heritage, with many objectives and stakeholders involved. A method of decision-making in the transport sector that allows for increased stakeholder participation in the multi-actor multi-criteria analysis (MAMCA) [28], [34]-[38]. MAMCA involves stakeholders from the start of the decision process [39]. Stakeholders argue explicitly, and different points of view are underlined separately to see differences in the performance of alternatives [28]. The different understanding of stakeholders can be implemented into a multi-criteria decision-making process. This can be applied in group decision models and extended into a complete methodology. The multi-actor multi-criteria analysis method, which is a derivative of MCDA [35], [40], incorporates stakeholders into the analysis so that it takes more time initially, but increases the likelihood that acceptance of the proposed solution will eventually be higher because all stakeholders are invited to view the criteria as a whole in the context of the sustainability of tourist destinations. All stakeholders can see the special and unique values, and there is no other place that becomes a tourist attraction to be able to preserve them. Stakeholder input is used primarily in the first three steps of the analysis: to determine alternative solutions, determine the selected stakeholders, and then assess criteria and their weights. This paper will assess the sustainable criteria of mobility in natural-cultural tourism protected areas as a tool to measure transportation policies by involving relevant stakeholdersthe steps in this research as shown in figure 2.

Step 1: Define the problem and identify alternatives that can be a solution. Furthermore, these alternatives can be combined in several scenarios by the problems faced related to mobility in protected areas of cultural nature tourism. Step 2: Next, the stakeholders involved are identified primarily for their purposes in the transport policy assessment of protected natural and cultural tourism areas. To achieve an acceptable measure, increase the legitimacy of the decision, the likelihood of implementation, and the quality of the results from various stakeholders must be considered in the calculations[28], [41]. Transportation projects usually involve more than one actor. The identification of stakeholders is carried out by analyzing historical, legislative, and administrative documents, accompanied by in-depth interviews with the community and interested parties. Most of the stakeholders are users, investors, operators, society as a 
whole, and government[42]. Stakeholder analysis identifies various stakeholders and takes them into account in the evaluation process. After certain stakeholders are identified, the surveyor interviews and asks the next stakeholder who needs to be involved or what is called the snowball sampling method[28]. Step 3: From the selected stakeholders, an interview is conducted on the appropriate criteria, as a tool to measure indicative transportation policies in protected areas of cultural nature tourism that support sustainable tourism and weighting the criteria of the stakeholders involved using the pairwise comparison method [28], [32].

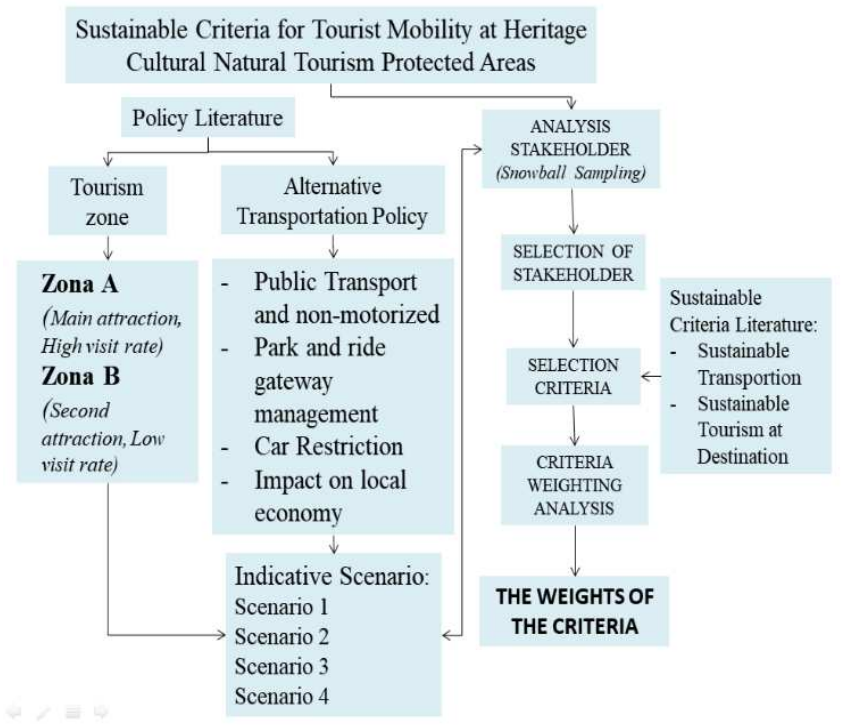

Fig. 2 Research flow chart

\section{RESULT AND DisCUSSION}

\section{A. The alternative becomes an indicative transportation policy scenario}

Based on the interviews, the relevant stakeholders selected several alternative solutions to compile several scenarios according to the conditions of tourist visits. Stakeholders implement traffic restrictions, public transport, nonmotorized transfer points, park and ride gateways management, and transfers of big or medium buses to small buses. Several alternative mobility model solutions in protected tourism areas are then integrated into indicative transportation policy scenarios as an illustration for stakeholders in selecting the right actors and assessing the criteria.

TABLE I

POLICY LITERATURE IN NATURAL TOURISM AREAS

\begin{tabular}{|c|c|}
\hline Alternatives & Description \\
\hline $\begin{array}{l}\text { Traffic } \\
\text { Restriction }\end{array}$ & $\begin{array}{l}\text { The high level of private vehicle use has resulted in } \\
\text { congestion, pollution, and parking difficulties so that } \\
\text { the National Park management applies a carrot and } \\
\text { stick pattern by limiting cars and providing } \\
\text { incentives in the form of public transportation to } \\
\text { explore the National Park. [26], [27] }\end{array}$ \\
\hline $\begin{array}{l}\text { Public } \\
\text { Transport } \\
\text { and non- } \\
\text { motorized: }\end{array}$ & $\begin{array}{l}\text { How to overcome capacity constraints, congestion } \\
\text { and environmental impacts, encourage the use of } \\
\text { non-motorized modes such as walking, cycling, } \\
\text { horse riding and the use of public transportation } \\
\text { modes [3], [18], [25], [43]-[53] }\end{array}$ \\
\hline
\end{tabular}

Park and ride The development of the Gateway with various \& gateway facilities makes many people want to park their cars management [54]-[56] and get around in other ways such as taking public transportation, cycling and walking without limiting access. Gateway is used to centralize visitors and the flow of traffic [26].

Impact on The Transportation Policy in the Tourism Area is Local successful if it has the support of the local Economy: community, one of the ways is by providing economic benefits to the local community [13], [24], [57].

Tourism Identify tourism zones based on tourist consumption, Zoning the intensity of specificity and not by administrative area. Areas with greater concentration and uniqueness of attractiveness have higher potential attractiveness[58]. Based on this theory, the Dieng tourist area is divided into zone $\mathrm{A}$ and Zone $\mathrm{B}$ based on the intensity of the visit and the specificity of the tourist attraction. Zone $\mathrm{A}$ is the main tourist area (Arjuna Temple area, Telaga Warna, Dieng Plateau Theater, Sikidang Crater and Kaliasa Museum). Zone B is a tourist area around Dieng with fewer enthusiasts (Merdada Lake, Sileri Crater, Jolotundo Well, Mount Prau Climbing etc.).

The results of interviews with related stakeholders produced four scenarios based on a combination of the number of visitors in the Dieng area (from of peak, half peak, peak on the weekend and extraordinary peak).

TABLE II

INDICATIVE SCENARIO TRANSPORT POLICY IN CULTURE-NATURE TOURISM PROTECTED AREA

\begin{tabular}{lllllllllll}
\hline \multirow{2}{*}{ No } & \multicolumn{1}{c}{ Alternative } & \multicolumn{2}{c}{ Sce 1 } & \multicolumn{2}{c}{ Sce 2 } & \multicolumn{2}{c}{ Sce 3 } & \multicolumn{2}{c}{ Sce 4 } \\
& \multicolumn{1}{c}{ Solution } & A & B & A & B & A & B & A & B \\
\hline 1 & Car restriction & - & - & V & - & V & - & V & V \\
2 & Public Transport & - & - & V & - & V & V & V & V \\
3 & $\begin{array}{l}\text { Transfer Point Non- } \\
\text { motorized }\end{array}$ & - & - & V & - & V & - & V & - \\
4 & $\begin{array}{l}\text { Park and ride \& } \\
\text { gateway management }\end{array}$ & - & - & V & - & V & V & - & V \\
& $\begin{array}{l}\text { Transfer Point Big to } \\
\text { Medium/small bus }\end{array}$ & - & V & - & V & - & V & - & V \\
\hline
\end{tabular}

\section{B. Stakeholders Analysis}

The stakeholders' determination was carried out by developing interviews with relevant stakeholders in the transportation and tourism sector. Transportation policy involves many stakeholders who are known as users, investors, operators, society as a whole, and government [42].

TABLE III

MULTI ACTOR INVOLVED IN DIENG TOURISM AREA

\begin{tabular}{llccc}
\hline \multicolumn{4}{c}{ Multi Actor Involved } \\
\hline & Regulator & Operator & Local & User \\
\hline \multirow{2}{*}{ National } & BPCB Jateng & & & \\
& BKSDA Jateng & & & \\
& Bappeda Jateng & Organda & Pokdarwis & \\
Province & Dishub Jateng & Jateng & Pandawa & ASIT \\
& Disporapar Jateng & & Pokdarwis & A \\
& Bappeda wonosobo & Organda & Dieng & IPI \\
& Dishub Wonosobo & Wonosobo & Kulon & ASPP \\
& Disparbud Wonosobo & & Paguyuban & I \\
& Bappeda Banjarnegara & & Homestay & \\
& Dishub Banjarnegara & Organda & & \\
& Disparbud & Banjarnegara & & \\
& Banjarnegara & & & \\
\hline
\end{tabular}


As in Table 3, stakeholders related to transportation policies in nature and cultural tourism protected areas involve the level of stakeholders, namely the National, Provincial, District, and local community levels, totaling 20 institutions.

1) National Government: This stakeholder group consists of two government actors, namely: a) Natural Resources Conservation Center of Central Java (BKSDA Jateng) is a stakeholder who has the authority to conserve natural resources in the Dieng area, including several lakes, namely: Dringo, Semurup, and Telogo Warno. b) Cultural Heritage
Conservation Center of Central Java (BPCB Jateng) is a stakeholder who can conserve the Cultural Heritage in Dieng tourist areas such as the Arjuna Temple Complex located in Dieng Kulon Village, Batur District, Banjarnegara Regency. There are five temple buildings in this complex, namely Arjuna Temple, Semar Temple, Srikandi Temple, Puntadewa Temple, and Sembadra Temple. Apart from Semar Temple, the other four temples are the main temples that are used as places of prayer or places for Galungan to be held and for cultural activities

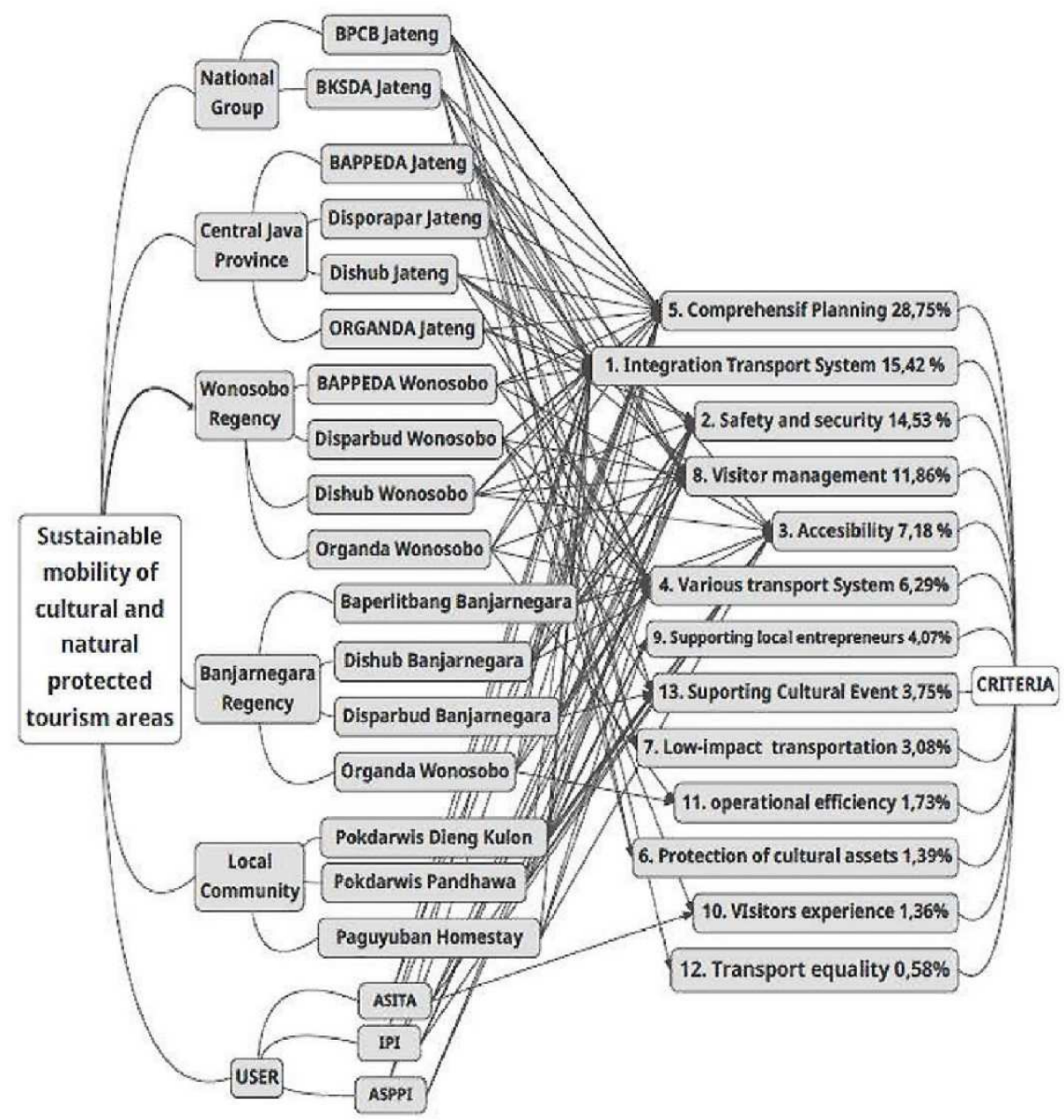

Fig. 3 Stakeholders and selected criteria

2) Central Java Provincial Group: At the stakeholder group level, there are four actors involved, namely: a) Regional Development Planning Agency of Central Java Province (Bappeda Jateng) as the stakeholder who has the authority for Development Planning in Central Java Province, b) Provincial Transportation Agency Central Java (Dishub Jateng) is a stakeholder who has the authority to organize intercity transport within the province, c) The Central Java Provincial Tourism Office (Dispar Jateng) is a government stakeholder in the tourism sector and d) the Central Java Land Transport Organization (ORGANDA Jateng) is a nongovernment stakeholder that is a combination of land transportation entrepreneurs.

3) Banjarnegara Regency Group: In this stakeholder group, there are four actors involved, namely: a) Research and
Development Planning Agency of Banjarnegara Regency (Baperlitbang Banjarnegara) as Banjarnegara District Development Planning, b) Transportation Office of Banjarnegara Regency (Dishub Banjarnegara) is a stakeholder who has authority in the field of transportation, c) Tourism and Culture Office of Banjarnegara Regency (Dispar Banjarnegara) is a government agency that has authority in the field of tourism and culture. d) Land Transportation Organization Banjarnegara (Organda Banjarnegara) is a nongovernmental organization associated with Land Transportation Entrepreneurs in the Banjarnegara Regency.

4) Wonosobo Regency Group: In this stakeholder group there are four actors involved, namely: a) Regional Planning and Development Agency of Wonosobo Regency (Bappeda Wonosobo) is a government stakeholder who plays a role in the development planning of Wonosobo Regency, b) 
Transportation Office of Wonosobo Regency (Dishub Wonosobo) is a stakeholder who has the authority in the Department of Transportation in the Wonosobo Regency area, c) Tourism and Culture Office of Wonosobo Regency (Dispar Wonosobo) is a government stakeholder who has authority in the tourism sector. d) The Wonosobo Land Transportation Organization (Organda Wonosobo) is a non-governmental organization whose members are public transportation companies in Wonosobo Regency.

5) Local Communities: Pokdarwis Dieng Pandhawa is a local community organization that drives the community in the tourism sector in Dieng Wetan Village. Pokdarwis Dieng Kulon is a local community organization as a driving force for tourism in Dieng Kulon Village. The homestay association is an association of Dieng residents who have a homestay business in the Dieng Tourism Area.

6) User or Tourist Group: To find out tourists' perceptions about transportation policies in the Dieng Cultural Nature Tourism Area, several non-government organizations can represent, namely: a) ASITA (Association of the Indonesian Tours and Travel Agencies), b) IPI (Insan Pariwisata Indonesia) a community of tourism actors in Indonesia which aims to strengthen brotherhood between fellow tourism actors, help each other, inform about various things about tourism and develop and introduce Indonesian tourism. c) ASPPI is the Association of Indonesian Tourism Actors.

\section{Criteria Analysis}

Furthermore, after an assessment of the criteria of the stakeholders involved regarding the objectives or criteria in determining the transportation policy in protected areas of nature cultural tourism, the weight of the criteria is produced as follows in Figure 4.

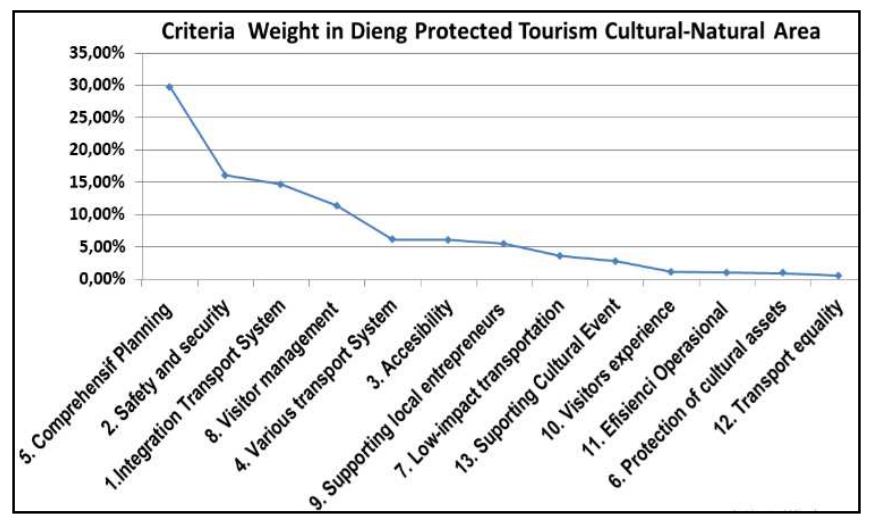

Fig. 4 Criteria Weight in Dieng Protected Tourism Heritage Cultural-Natural Area

TABLE IV

ASSESSMENT OF MOBILITY CRITERIA IN NATURAL AND CULTURAL TOURISM PROTECTED AREAS BY STAKEHOLDERS

\begin{tabular}{clcc}
\hline Rank & \multicolumn{1}{c}{ Criteria } & $\begin{array}{c}\text { Weight } \\
\text { Criteria }\end{array}$ & $\begin{array}{c}\text { Actors } \\
\text { Involved }\end{array}$ \\
\hline 1 & 5. Comprehensive Planning & $28,75 \%$ & 17 \\
2 & 1.Integration Transport System & $15,42 \%$ & 20 \\
3 & 2. Safety and security & $14,53 \%$ & 10 \\
4 & 8. Visitor management & $11,86 \%$ & 12 \\
5 & 3. Accessibility & $7,18 \%$ & 11 \\
6 & 4. Various transport System & $6,29 \%$ & 13 \\
7 & 9. Supporting local entrepreneurs & $4,07 \%$ & 3 \\
8 & 13. Supporting Cultural Event & $3,75 \%$ & 5 \\
\hline
\end{tabular}

\begin{tabular}{clll}
\hline 9 & 7. Low-impact transportation & $3,08 \%$ & 3 \\
10 & 11. Efficiency Operational & $1,73 \%$ & 2 \\
11 & 6. Protection of cultural assets & $1,39 \%$ & 2 \\
12 & 10. Visitor's experience & $1,36 \%$ & 2 \\
13 & 12. Transport equality & $0,58 \%$ & 1 \\
\hline
\end{tabular}

Based on the research results, it can be seen that the priority weights of the criteria for sustainable mobility and the number of stakeholders involved in the natural and culturally protected tourism areas using the participatory stakeholder method are shown in Table 4.

1. Comprehensive planning is the first assessment criterion with a value of $28.75 \%$, with support from 17 relevant stakeholders.

2. Integrated transportation system is the second criterion chosen with a criterion weight of $15.42 \%$ and selected by 20 relevant stakeholders.

3. Safety and security is the third criterion with a criterion weight of $14.53 \%$ and selected by 10 related stakeholders

4. Visitor management is the fourth criterion with a criterion weight of $11.86 \%$ and was selected by 12 stakeholders.

5. Accessibility is the fifth criterion with a criterion weight of $7.18 \%$ and was selected by 11 stakeholders.

6. The various transport system is the sixth criterion with a criterion weight of $6.29 \%$ and selected by 13 stakeholders.

7. Supporting local entrepreneurs is the seventh criterion by weight of $4.07 \%$ and selected by 3 stakeholders.

8. The supporting cultural event is the eighth criterion by weight of $3.75 \%$ and selected by 5 stakeholders.

9. Low impact transportation is the ninth criterion by weight of $3.08 \%$ and selected by 3 stakeholders.

10. Efficient transport operation is the tenth criterion by weight $1.73 \%$ and selected by 2 stakeholders.

11. Protection of cultural assets is the eleventh criterion by weight $1.39 \%$ and selected by 2 stakeholders.

12. The visitor experience is the twelfth criterion by weight $1.36 \%$ and selected by 2 stakeholders.

13. Transport equality is the thirteenth criterion by weight $0.58 \%$ and is chosen by 1 stakeholder.

Protected area destinations are very complex due to the interaction of interests in one area, the large number of stakeholders who have different interests and views on tourism, conservation, and transportation in protected natural and cultural heritage tourism areas. This can be seen from the selection of criteria and assessment criteria for stakeholders. Conservation areas as tourist attractions that often occur in protected area destinations indicate the need for stakeholder participation in assessing transportation policies to ensure that conservation and tourism work in a balanced manner for sustainable destination management. Stakeholders cannot separately view the preservation of natural resources and cultural heritage. The impacts will be interrelated, and various stakeholders, local communities, district, provincial and national, are needed to address this problem.

Stakeholders must consider the objectives and criteria in the analysis to be successful. Each actor has different criteria in the analysis. Multi-actor multi-criteria analysis allows each stakeholder to have different criteria. The criteria in each actor 
count as a score of one or $100 \%$. The more choice of stakeholder criteria, the smaller the weight of the criteria, and vice versa, the fewer criteria selected, the greater the weight. This means that stakeholders are increasingly focused on the criteria selected according to their fields. The more criteria selected can cause bias in the assessment. On the other hand, if more and more stakeholders choose a certain criterion, the criterion's weight will be higher in value. Further research criteria were selected and used as a tool to measure indicative alternative scenarios of transportation policy in sustainable tourist destinations.

\section{CONCLUSION}

A natural-cultural tourism protected area is an extraordinary area that involves various stakeholders with different criteria. Transportation policies to support sustainable destination mobility must be integrated between tourism, conservation, and transportation policies. Current conditions indicate a lack of coordination from stakeholders, and they see sustainability goals only from the point of view of their respective institutions. Each stakeholder is expected to be able to see the criteria for sustainability fully and not only from their perspective, but stakeholders see that they are part of the overall stakeholder environment that supports the destination of a sustainable natural-cultural tourism protected area. Natural-cultural tourism protected areas have special criteria for conserving nature-culture and tourism that drives the local economy. Thirteen criteria from the results of this study are used as comprehensive parameters to measure transportation policies that support mobility in sustainable tourist destinations. In this assessment, the involvement of each stakeholder is the same, with different criteria for each stakeholder. In the end, comprehensive planning is the criterion with the highest weight. In future research, it is necessary to evaluate whether only the weight of the criteria affects this assessment? are there no other factors? In this case, the authors highlight the involvement of stakeholders in determining sustainability criteria. Some are related directly or indirectly. There are also government stakeholders and non-government stakeholders, which must be considered so that there is no bias in the assessment.

\section{ACKNOWLEDGMENT}

We express our deepest gratitude to Central Java Cultural Heritage Conservation Center, Central Java Natural Resources Conservation Center, Central Java Province Regional Development Planning Agency, Central Java Provincial Transportation Office, Central Java Provincial Tourism Office, Central Java Land Transportation Organization, Regional Development Planning Agency of Wonosobo Regency, Transportation Department of Wonosobo Regency, Tourism and Culture Service of Wonosobo Regency, Wonosobo Land Transportation Organization, Research and Development Planning Agency of Banjarnegara Regency, Transportation Department of Banjarnegara Regency, Tourism and Culture Service of Banjarnegara Regency, Banjarnegara Land Transportation Organization, Pokdarwis Pandawa Dieng Kulon and Dieng Wetan, ASITA, IPI and ASPPI Central Java, who have helped carry out this research.

\section{REFERENCES}

[1] GSTC, "GSTC Destination Criteria Version 2.0 with Performance indicators and SDGs," 2019.

[2] T. Litman, "Transportation indicators for sustainability (Miscellaneous) |ETDEWEB," 2015.

[3] S. Gross and B. Grimm, "Sustainable mode of transport choices at the destination - public transport at German destinations," Tour. Rev., vol. 73, no. 3, pp. 401-420, Aug. 2018, doi: 10.1108/TR-11-2017-0177.

[4] D. Hopkins, "Sustainable mobility at the interface of transport and tourism: Introduction to the special issue on 'Innovative approaches to the study and practice of sustainable transport, mobility and tourism," J. Sustain. Tour., vol. 28, no. 2, pp. 225-239, Feb. 2020, doi: 10.1080/09669582.2019.1691800.

[5] R. Manning, S. Lawson, P. Newman, J. Halo, and C. Monz, "Principles of Sustainable Transportation in the National Parks," Environ. Soc. Fac. Publ., 2014.

[6] A. Smith, D. Robbins, and J. E. Dickinson, "Defining sustainable transport in rural tourism: experiences from the New Forest," $J$ Sustain. Tour., vol. 27, no. 2, pp. 258-275, Feb. 2019, doi: 10.1080/09669582.2017.1401633.

[7] C. M. Hall and Y. Ram, "Measuring the relationship between tourism and walkability? Walk Score and English tourist attractions," $J$ Sustain. Tour., vol. 27, no. 2, pp. 223-240, Feb. 2019, doi: 10.1080/09669582.2017.1404607.

[8] C. Gonson, D. Pelletier, F. Alban, C. Giraud-Carrier, and J. Ferraris, "Influence of settings management and protection status on recreational uses and pressures in marine protected areas," J. Environ. Manage., vol. 200, pp. 170-185, Sep. 2017, doi: 10.1016/j.jenvman.2017.05.051.

[9] M. Díez Gutiérrez, T. Tørset, E. Skjetne, and J. Odeck, “Tourist traffic simulation as a protected area management tool. The case of Serengeti National Park in Tanzania," Tour. Manag. Perspect., vol. 22, pp. 54 63, Apr. 2017, doi: 10.1016/j.tmp.2017.01.005.

[10] N. Bošković, M. Vujičić, and L. Ristić, "Sustainable tourism development indicators for mountain destinations in the Republic of Serbia," Curr. Issues Tour., vol. 23, no. 22, pp. 2766-2778, Nov. 2020, doi: 10.1080/13683500.2019.1666807.

[11] N. D. Md Khairi, H. N. Ismail, and S. M. R. Syed Jaafar, "Tourist behaviour through consumption in Melaka World Heritage Site," Curr. Issues Tour., vol. 22, no. 5, pp. 582-600, Mar. 2019, doi: 10.1080/13683500.2018.1491534

[12] B. L. Mace, J. D. Marquit, and S. C. Bates, "Visitor Assessment of the Mandatory Alternative Transportation System at Zion National Park," Environ. Manage., 2013, doi: 10.1007/s00267-013-0164-z.

[13] A. E. Dunning, "Impacts of Transit in National Parks and Gateway Communities," Transp. Res. Rec. J. Transp. Res. Board, vol. 1931, no. 1, pp. 129-136, Jan. 2005, doi: 10.1177/0361198105193100116.

[14] J. E. Dickinson and J. A. Dickinson, "Local transport and social representations: Challenging the assumptions for sustainable tourism," J. Sustain. Tour., vol. 14, no. 2, pp. 192-208, 2006, doi: $10.1080 / 09669580608669052$.

[15] P. Næss, J. Xue, H. Stefansdottir, R. Steffansen, and T. Richardson, "Second home mobility, climate impacts and travel modes: Can sustainability obstacles be overcome?," J. Transp. Geogr., vol. 79, p. 102468, Jul. 2019, doi: 10.1016/j.jtrangeo.2019.102468.

[16] A. Scuttari, F. Orsi, and R. Bassani, "Assessing the tourism-traffic paradox in mountain destinations. A stated preference survey on the Dolomites' passes (Italy)," J. Sustain. Tour., vol. 27, no. 2, pp. 241257, Feb. 2019, doi: 10.1080/09669582.2018.1428336.

[17] F. Cavallaro, F. Ciari, S. Nocera, F. Prettenthaler, and A. Scuttari, "The impacts of climate change on tourist mobility in mountain areas," J. Sustain. Tour., vol. 25, no. 8, pp. 1063-1083, Aug. 2017, doi: 10.1080/09669582.2016.1253092.

[18] R. M. González, C. Román, and J. de D. Ortúzar, "Preferences for sustainable mobility in natural areas: The case of Teide National Park," J. Transp. Geogr., vol. 76, pp. 42-51, Apr. 2019, doi: 10.1016/j.jtrangeo.2019.03.002.

[19] L. Li, W. Liu, L. Xiao, H. Sun, and S. Wang, "Environmental Protection in Scenic Areas: Traffic Scheme for Clean Energy Vehicles Based on Multi-agent," Comput. Econ., vol. 52, no. 4, pp. 1069-1087, Dec. 2018, doi: 10.1007/s10614-017-9790-5

[20] D. L. Wilson, J. C. Hallo, F. A. McGuire, J. L. Sharp, and F. P. Mainella, "Transportation mode choice among baby boomer visitors in national parks: Exploring the concept of freedom," Travel Behav. Soc., vol. 13, pp. 61-70, Oct. 2018, doi: 10.1016/j.tbs.2018.06.001. 
[21] C. M. Hall, "Constructing sustainable tourism development: The 2030 agenda and the managerial ecology of sustainable tourism," J. Sustain. Tour., vol. 27, no. 7, pp. 1044-1060, Jul. 2019, doi $10.1080 / 09669582.2018 .1560456$

[22] F. Orsi, A. Scuttari, and A. Marcher, "How much traffic is too much? Finding the right vehicle quota for a scenic mountain road in the Italian Alps," Case Stud. Transp. Policy, vol. 8, no. 4, pp. 1270-1284, Dec. 2020, doi: 10.1016/j.cstp.2020.08.007.

[23] V. de Gooyert, E. Rouwette, H. van Kranenburg, and E. Freeman, "Reviewing the role of stakeholders in Operational Research: A stakeholder theory perspective," European Journal of Operational Research, vol. 262, no. 2. Elsevier B.V., pp. 402-410, Oct. 2017, doi: 10.1016/j.ejor.2017.03.079.

[24] L. Joyner, N. Q. Lackey, and K. S. Bricker, "Community Engagement: An Appreciative Inquiry Case Study with Theodore Roosevelt National Park Gateway Communities," Sustainability, vol. 11, no. 24, p. 7147, Dec. 2019, doi: 10.3390/su11247147.

[25] D.-T. Le-Klähn and C. M. Hall, "Tourist use of public transport at destinations - a review," Curr. Issues Tour., vol. 18, no. 8, pp. 785 803, Aug. 2015, doi: 10.1080/13683500.2014.948812.

[26] H. D. Regnerus, R. Beunen, and C. F. Jaarsma, "Recreational traffic management: The relations between research and implementation," Transp. Policy, 2007, doi: 10.1016/j.tranpol.2007.02.002.

[27] A. Scuttari, M. Volgger, and H. Pechlaner, "Transition management towards sustainable mobility in Alpine destinations: realities and realpolitik in Italy's South Tyrol region," J. Sustain. Tour., vol. 24, no. 3, pp. 463-483, Mar. 2016, doi: 10.1080/09669582.2015.1136634

[28] C. Macharis, L. Turcksin, and K. Lebeau, "Multi actor multi criteria analysis (MAMCA) as a tool to support sustainable decisions: State of use," Decis. Support Syst., vol. 54, no. 1, pp. 610-620, Dec. 2012, doi: 10.1016/j.dss.2012.08.008.

[29] I. Keseru, J. Bulckaen, and C. Macharis, "Sustainable, Participatory and Practical: The NISTO Evaluation Framework for Urban and Regional Mobility Projects," in Transportation Research Procedia, Jan. 2016, vol. 13, pp. 134-144, doi: 10.1016/j.trpro.2016.05.014.

[30] B. Purvis, Y. Mao, and D. Robinson, "Three pillars of sustainability: in search of conceptual origins," Sustain. Sci., vol. 14, no. 3, pp. 681695, May 2019, doi: 10.1007/s11625-018-0627-5.

[31] D. Nag, S. K. Paul, S. Saha, and A. K. Goswami, "Sustainability assessment for the transportation environment of Darjeeling, India," $J$ Environ. Manage., vol. 213, pp. 489-502, May 2018, doi: 10.1016/j.jenvman.2018.01.042

[32] A. Roukouni, C. Macharis, S. Basbas, B. Stephanis, and G. Mintsis, "Financing urban transportation infrastructure in a multi-actors environment: the role of value capture," Eur. Transp. Res. Rev., vol. 10, no. 1, pp. 1-19, Mar. 2018, doi: 10.1007/s12544-017-0281-5.

[33] Central Java Province, "Central Java Provincial Government Regulation Number 6, Concerning the Regional Spatial Plan for Central JavaProvince," 2010.

[34] C. Macharis and A. Bernardini, "Reviewing the use of multi-criteria decision analysis for the evaluation of transport projects: Time for a multi-actor approach," Transp. Policy, vol. 37, pp. 177-186, Jan. 2015, doi: 10.1016/j.tranpol.2014.11.002.

[35] G. Yannis, A. Kopsacheili, A. Dragomanovits, and V. Petraki, "Stateof-the-art review on multi-criteria decision-making in the transport sector," Journal of Traffic and Transportation Engineering (English Edition), vol. 7, no. 4. Periodical Offices of Chang- an University, pp. 413-431, Aug. 2020, doi: 10.1016/j.jtte.2020.05.005.

[36] G. Baudry, C. Macharis, and T. Vallée, "Range-based Multi-Actor Multi-Criteria Analysis: A combined method of Multi-Actor MultiCriteria Analysis and Monte Carlo simulation to support participatory decision making under uncertainty," Eur. J. Oper. Res., vol. 264, no. 1, pp. 257-269, Jan. 2018, doi: 10.1016/j.ejor.2017.06.036.

[37] A. Sirikijpanichkul, S. Winyoopadit, and A. Jenpanitsub, "A multiactor multi-criteria transit system selection model: A case study of Bangkok feeder system," in Transportation Research Procedia, Jan 2017, vol. 25, pp. 3736-3755, doi: 10.1016/j.trpro.2017.05.228.

[38] I. Keseru, T. Coosemans, and C. Macharis, "Stakeholders' preferences for the future of transport in Europe: Participatory evaluation of scenarios combining scenario planning and the multi-actor multicriteria analysis," Futures, vol. 127, p. 102690, Mar. 2021, doi 10.1016/j.futures.2020.102690.

[39] H. Huang, "Collaborative decision-making in sustainable mobility: identifying possible consensuses in the multi-actor multi-criteria analysis based on inverse mixed-integer linear optimization," Int. $J$
Sustain. Dev. World Ecol., pp. 1-11, 2020, doi: 10.1080/13504509.2020.1795005.

[40] M. Marttunen, J. Lienert, and V. Belton, "Structuring problems for Multi-Criteria Decision Analysis in practice: A literature review of method combinations," European Journal of Operational Research, vol. 263, no. 1. Elsevier B.V., pp. 1-17, Nov. 2017, doi: 10.1016/j.ejor.2017.04.041.

[41] A. Scolobig and J. Lilliestam, "Comparing Approaches for the Integration of Stakeholder Perspectives in Environmental Decision Making," Resources, vol. 5, no. 4, p. 37, Nov. 2016, doi: 10.3390/resources5040037.

[42] C. Macharis, A. De Witte, and J. Ampe, "The multi-actor, multicriteria analysis methodology (MAMCA) for the evaluation of transport projects: Theory and practice," J. Adv. Transp., vol. 43, no. 2,pp. 183-202, Apr. 2009, doi: 10.1002/atr.5670430206.

[43] W. den Hoed, "Where everyday mobility meets tourism: an agefriendly perspective on cycling in the Netherlands and the UK," $J$. Sustain. Tour., vol. 28, no. 2, pp. 185-203, Feb. 2020, doi 10.1080/09669582.2019.1656727

[44] C. Tolls and N. Carr, "The role of nature on horse trail rides: touris experience expectations," Curr. Issues Tour., pp. 1-13, Jun. 2020, doi: 10.1080/13683500.2020.1774515.

[45] M. Shaker et al., "Facilitating hikers' mobility in protected areas through smartphone app: a case of the Hoge Kempen National Park Belgium," Pers. Ubiquitous Comput., 2020, doi: 10.1007/s00779-02001367-6.

[46] W. Gronau, "Encouraging behavioural change towards sustainable tourism: a German approach to free public transport for tourists," $J$. Sustain. Tour., vol. 25, no. 2, pp. 265-275, Feb. 2017, doi: $10.1080 / 09669582.2016 .1198357$

[47] K. Tomej and J. J. Liburd, "Sustainable accessibility in rural destinations: a public transport network approach," J. Sustain. Tour., vol. 28, no. 2, pp. 222-239, Feb. 2020, doi: 10.1080/09669582.2019.1607359

[48] R. Y. Nutsugbodo, E. K. Amenumey, and C. A. Mensah, "Public transport mode preferences of international tourists in Ghana: Implications for transport planning," Travel Behav. Soc., vol. 11, pp. 1-8, Apr. 2018, doi: 10.1016/j.tbs.2017.11.002.

[49] C. Médard de Chardon, "The contradictions of bike-share benefits, purposes and outcomes," Transp. Res. Part A Policy Pract., vol. 121, pp. 401-419, Mar. 2019, doi: 10.1016/j.tra.2019.01.031.

[50] J. Pucher and R. Buehler, "Cycling towards a more sustainable transport future," Transport Reviews, vol. 37, no. 6. Routledge, pp. 689-694, Nov. 2017, doi: 10.1080/01441647.2017.1340234.

[51] A. Hardy and J. Aryal, "Using innovations to understand tourist mobility in national parks," J. Sustain. Tour., vol. 28, no. 2, pp. 263 283, Feb. 2020, doi: 10.1080/09669582.2019.1670186.

[52] L. Zhang, Y. P. Wang, J. Sun, and B. Yu, "The sightseeing bus schedule optimization under Park and Ride System in touris attractions," Ann. Oper. Res., vol. 273, no. 1-2, pp. 587-605, Feb. 2019, doi: 10.1007/s10479-016-2364-4.

[53] C. M. Hall and Y. Ram, "Walk score $₫$ and its potential contribution to the study of active transport and walkability: A critical and systematic review," Transp. Res. Part D Transp. Environ., vol. 61, pp. 310-324, Jun. 2018, doi: 10.1016/j.trd.2017.12.018.

[54] D. C. Weitowitz, C. Panter, R. Hoskin, and D. Liley, "Parking provision at nature conservation sites and its implications for visitor use," Landsc. Urban Plan., vol. 190, Oct. 2019, doi: 10.1016/j.landurbplan.2019.103597.

[55] J. N. Newton, P. Newman, B. D. Taff, Y. H. Shr, C. Monz, and A. D'Antonio, "If i can find a parking spot: A stated choice approach to Grand Teton National Park visitors' transportation preferences," $J$ Outdoor Recreat. Tour., May 2018, doi: 10.1016/j.jort.2018.04.001.

[56] G. Antolín, B. Alonso, R. Cordera, and L. dell'Olio, "The Effect of Introducing Parking Policies on Managing Mobility to Beaches in Touristic Coastal Towns," Sustainability, vol. 11, no. 13, p. 3528, Jun. 2019, doi: 10.3390/su11133528.

[57] P. Wassler, T. H. H. Nguyen, L. Q. Mai, and M. Schuckert, "Socia representations and resident attitudes: A multiple-mixed-method approach," Ann. Tour. Res., vol. 78, p. 102740, Sep. 2019, doi: 10.1016/j.annals.2019.06.007.

[58] D. Blasco, J. Guia, and L. Prats, "Tourism destination zoning in mountain regions: A consumer-based approach," Tour. Geogr., vol 16, no. 3, pp. 512-528, 2014, doi: 10.1080/14616688.2013.851267. 